\title{
Pseudomonas guineae sp. nov., a novel psychrotolerant bacterium from an Antarctic environment
}

\author{
Núria Bozal, M. Jesús Montes and Elena Mercadé \\ Laboratori de Microbiologia, Facultat de Farmacia, Universitat de Barcelona, Av. Joan XXIII s/n, \\ 08028 Barcelona, Spain
}

Correspondence

Elena Mercadé

mmercade@ub.edu

\begin{abstract}
Two Gram-negative, cold-adapted, aerobic bacteria, designated strains $\mathrm{M}^{\top}{ }^{\top}$ and $\mathrm{M} 6$, were isolated from soil collected from the South Shetland Islands. The organisms were rod-shaped, catalase- and oxidase-positive and motile by means of polar flagella. These two psychrotolerant strains grew between -4 and $30{ }^{\circ} \mathrm{C}$. 16S rRNA gene sequence analysis placed strains $\mathrm{M}^{\top}$ and M6 within the genus Pseudomonas. DNA-DNA hybridization experiments between the Antarctic isolate $\mathrm{M}^{\top}$ and type strains of phylogenetically related species, namely Pseudomonas peli and Pseudomonas anguilliseptica, revealed levels of relatedness of 33 and $37 \%$, respectively. Strain M6 showed $99 \%$ DNA similarity to strain $M 8^{\top}$. Several phenotypic characteristics, together with data on cellular fatty acid composition, served to differentiate strains $M 8^{\top}$ and $\mathrm{M} 6$ from related pseudomonads. On the basis of the polyphasic taxonomic evidence presented in this study, it can be concluded that strains $M 8^{\top}$ and $M 6$ belong to the same genospecies, representing a novel species of the genus Pseudomonas, for which the name Pseudomonas guineae sp. nov. is proposed. The type strain is $\mathrm{M8}^{\top}$ (=LMG $24016^{\top}=\mathrm{CECT}$ $7231^{\top}$ ).
\end{abstract}

In recent years, increasing attention has been devoted to cold-adapted micro-organisms and their enzymes (Antranikian et al., 2005). Antarctica has become a great source of novel psychrophilic and psychrotolerant strains, some of which belong to the genus Pseudomonas (Kriss et al., 1976; Shivaji et al., 1989; Ma et al., 2006; Maugeri et al., 1996; Bruni et al., 1999; Reddy et al., 2004). The genus Pseudomonas once comprised more than 100 species, but, over the last decade, many of these have been reclassified into different genera (Kersters et al., 1996; Anzai et al., 2000). During a taxonomic investigation of cold-adapted bacteria from soil samples collected in the Antarctic area of the South Shetland Islands, two strains, M6 and $\mathrm{M}^{\mathrm{T}}$, able to grow at $-4{ }^{\circ} \mathrm{C}$ and capable of forming swarming colonies on trypticase soy agar (TSA) were isolated. In this study, the taxonomic status of these two strains was investigated by using a combination of phenotypic characterization, 16S rRNA gene sequencing, DNA G + C content determination, DNA-DNA hybridization and cellular fatty acid analysis. The data obtained

The GenBank/EMBL/DDBJ accession numbers for the 16S rRNA gene sequences of strains $M 8^{\top}$ and $M 6$ are AM491810 and AM491811, respectively.

An electron micrograph of a cell of strain $\mathrm{M}^{\top}$, an extended phylogenetic tree for strains $\mathrm{MB}^{\top}$ and $\mathrm{M} 6$ within the genus Pseudomonas and a table showing cellular fatty acid compositions are available with the online version of this paper. show that strains M6 and $\mathrm{M}^{\mathrm{T}}$ belong to a novel species of the genus Pseudomonas, for which the name Pseudomonas guineae sp. nov. is proposed, with $\mathrm{M}^{\mathrm{T}}$ as the type strain.

Strains $\mathrm{M}^{\mathrm{T}}$ and $\mathrm{M} 6$ were isolated from a soil sample collected from Deception Island (South Shetland Islands, Antarctica). Sample aliquots were removed with a platinum loop and diluted in a saline solution $(\mathrm{pH} \mathrm{7})$ containing the following salts $\left(\mathrm{g} \mathrm{l}^{-1}\right)$ : $\mathrm{NaCl}, 0.56 ; \mathrm{KCl}$, 0.027; $\mathrm{CaCl}_{2}, 0.03 ; \mathrm{NaHCO}_{3}, 0.01$. TSA plates were inoculated with loopfuls of several sample dilutions by using the streak-plate method to obtain isolated colonies. Plates were incubated for 4 days at $15{ }^{\circ} \mathrm{C}$. Isolates were maintained aerobically on TSA slopes at $4{ }^{\circ} \mathrm{C}$ and also at $-80{ }^{\circ} \mathrm{C}$ on cryo-beads.

The morphology, cell size and shape of cells grown on TSA at $15{ }^{\circ} \mathrm{C}$ were determined by means of negative staining and transmission electron microscopy. Motility was determined by phase-contrast microscopy. Oxidase, catalase and urease activities, nitrate reduction and hydrolysis of casein, lecithin, gelatin, DNA, starch and Tween 80 were determined according to Cowan \& Steel (1993). The presence of fluorescent pigments was tested under UV light after 8 days on King's B medium (King et al., 1954). Acid production from carbohydrates, enzyme production and additional characteristics were determined by using API 50 $\mathrm{CH}$, API ZYM and API 20NE strips (bioMérieux). Tolerance of $\mathrm{NaCl}$ was measured on nutrient agar 
containing $0.5-7.5 \%(\mathrm{w} / \mathrm{v}) \mathrm{NaCl}$; plates were incubated at $15{ }^{\circ} \mathrm{C}$ for 30 days. The temperature range for growth was determined on TSA incubated for 14 days at temperatures from -4 to $37{ }^{\circ} \mathrm{C}$. Anaerobic growth was determined on trypticase soy broth (TSB) plus $1.5 \%$ agar-agar and on Marine agar (Difco) after incubation in an anaerobic chamber at $15{ }^{\circ} \mathrm{C}$ for 14 days.

The cells were Gram-negative, rod-shaped (0.4-0.5 $\mu \mathrm{m}$ wide and 1.5-2.0 $\mu \mathrm{m}$ long) and motile by means of polar flagella (see Supplementary Fig. S1, available in IJSEM Online). Colonies of the isolates grown on TSA at $15{ }^{\circ} \mathrm{C}$ for $72 \mathrm{~h}$ were non-pigmented, round with irregular edges, slightly convex, $1.5-2.0 \mathrm{~mm}$ in diameter and did not produce fluorescent pigment on King's B medium. After 1 week, colonies had swarmed over the plate, merging together and becoming more mucous. The isolates grew at temperatures ranging from -4 to $30{ }^{\circ} \mathrm{C}$ and tolerated $\mathrm{NaCl}$ concentrations up to $4 \%(\mathrm{w} / \mathrm{v})$ on TSA. The isolates were positive for the hydrolysis of lecithin and negative for the hydrolysis of casein, starch, Tween 80 and DNA. Other phenotypic characteristics of the Antarctic isolates and their closest phylogenetic relatives are shown in Table 1 . These phenotypic studies showed that the isolates displayed characteristics consistent with those for the genus Pseudomonas.

Fatty acids were prepared from $40 \mathrm{mg}$ wet cell material harvested from a TSB agar culture $\left(30 \mathrm{~g} \mathrm{TSB}^{-1}\right.$ and $15 \mathrm{~g}$ agar $1^{-1}$ ) incubated for 4 days at $15{ }^{\circ} \mathrm{C}$. The whole-cell fatty acids were determined as described previously (Bozal et al., 2002). The mean fatty acid compositions of strains $M 8^{\mathrm{T}}$ and M6, together with those of type strains of the closest phylogenetic neighbours, are shown in Supplementary Table S1 (available in IJSEM Online). The most abundant fatty acids were $\mathrm{C}_{16: 0}, \mathrm{C}_{18: 1} \omega 7 c$ and summed feature $3\left(\mathrm{C}_{16: 1} \omega 7 c\right.$ and/or iso- $\left.\mathrm{C}_{15: 0} 2-\mathrm{OH}\right)$. The isolates had cellular fatty acid profiles similar to that of Pseudomonas peli LMG 23201 ${ }^{\mathrm{T}}$, containing the same percentages of $\mathrm{C}_{16: 0}$ and $\mathrm{C}_{18: 1} \omega 07 c$, whereas the summed feature 3 content was lower for $P$. peli. Pseudomonas anguilliseptica LMG $21629^{\mathrm{T}}$ contained a significantly higher proportion of $\mathrm{C}_{16: 0}$ and also had a smaller proportion of summed feature 3 .

Total DNA for complete 16S rRNA gene sequence analysis was prepared according to the protocol of Niemann et al. (1997). Phylogenetic analyses were carried out by using the neighbour-joining method as described previously by Bozal et al. (2002), with the software package BioNumerics (Applied Maths). For DNA-DNA hybridizations and determination of the $\mathrm{G}+\mathrm{C}$ content, total DNA was prepared according to a modification of the procedure of Wilson (1987). The $\mathrm{G}+\mathrm{C}$ content was determined by using the HPLC technique, as described by Mesbah et al. (1989). The DNA-DNA hybridizations were performed at $47^{\circ} \mathrm{C}$ according to a modification (Goris et al., 1998; Cleenwerck et al., 2002) of the method described by Ezaki et al. (1989).

$16 \mathrm{~S}$ rRNA phylogenetic studies confirmed that the Antarctic isolates (strains $\mathrm{M}^{\mathrm{T}}$ and $\mathrm{M} 6$ ) were members of
Table 1. Phenotypic characteristics of strains $M 8^{\top}$ and $M 6$ and their closest phylogenetic neighbours

Strains: $1, \mathrm{M}^{\mathrm{T}} ; 2$, M6; 3, P. peli LMG $23201^{\mathrm{T}}$ [data from Vanparys et al. (2006)]; 4, P. anguilliseptica LMG $21629^{\mathrm{T}}$ [data from Vanparys et al. (2006)]. All strains are positive for oxidase, catalase, leucine arylamidase and naphthol-AS-BI-phosphohydrolase. All are negative for trypsin, chymotrypsin, $\alpha$-galactosidase, $\beta$-galactosidase, $\beta$-glucuronidase, $\beta$-glucosidase, $\beta$-glucosidase, $N$-acetyl- $\beta$-glucosaminidase, $\alpha$-mannosidase, $\alpha$-fucosidase, indole production, acidification of glucose, arginine dihydrolase, urease, aesculin hydrolysis, gelatin hydrolysis and the assimilation of glycerol, L-arabinose, D-ribose, Dglucose, D-fructose, D-mannose, D-mannitol, $N$-acetylglucosamine, Dmaltose, D-sucrose, D-trehalose, D-arabitol, gluconate, adipate, phenylacetate, erythritol, D-arabinose, L-xylose, D-adonitol, methyl $\beta$-D-xyloside, L-sorbose, L-rhamnose, dulcitol, inositol, D-sorbitol, methyl $\alpha$-D-mannoside, methyl $\alpha$-D-glucoside, amygdalin, arbutin, aesculin, salicin, D-cellobiose, D-lactose, D-melibiose, inulin, Dmelezitose, D-raffinose, starch, glycogen, xylitol, gentiobiose, Dturanose, D-lyxose, D-tagatose, D- and L-fucose, L-arabitol and 2- and 5-ketogluconate. + , Positive; $\mathrm{W}$, weakly positive; -, negative.

\begin{tabular}{|lcccc|}
\hline Characteristic & $\mathbf{1}$ & $\mathbf{2}$ & $\mathbf{3}$ & $\mathbf{4}$ \\
\hline Growth at $4{ }^{\circ} \mathrm{C}$ & + & + & - & + \\
Nitrate reduction & - & - & - & + \\
Enzyme activities & & & & \\
$\quad$ Alkaline phosphatase & + & + & - & $\mathrm{W}$ \\
Esterase & + & + & - & - \\
Esterase lipase & + & + & + & - \\
Lipase & + & + & $\mathrm{W}$ & - \\
Valine arylamidase & + & + & - & - \\
Cystine arylamidase & + & + & - & - \\
Acid phosphatase & + & + & - & + \\
Assimilation of: & & & & \\
D-Galactose & - & - & - & + \\
Caprate & + & + & - & + \\
Malate & + & + & + & + \\
Citrate & + & + & - & + \\
\hline
\end{tabular}

the genus Pseudomonas. The highest level of 16S rRNA gene sequence similarity $(99.1 \%)$ was found with $P$. peli LMG $23201^{\mathrm{T}}$; lower levels of similarity occurred with other Pseudomonas species with validly published names (Fig. 1; Supplementary Fig. S2, available in IJSEM Online, shows the complete phylogenetic tree). Strain M6 showed 100.0\% $16 \mathrm{~S}$ rRNA gene sequence similarity to $\mathrm{M} 8^{\mathrm{T}}$, indicating that these strains probably belong to the same species. To verify the taxonomic position of strain $\mathrm{M}^{\mathrm{T}}$, DNA-DNA hybridizations were performed with $P$. peli LMG $23201^{\mathrm{T}}$ and P. anguilliseptica LMG $21629^{\mathrm{T}}$. The low DNA-DNA reassociation values (33\% with P. peli LMG $23201^{\mathrm{T}}$ and $37 \%$ with $P$. anguilliseptica LMG $21629^{\mathrm{T}}$ ) and the $16 \mathrm{~S}$ rRNA gene sequence data indeed showed that strain $M 8^{\mathrm{T}}$ occupies a distinct position within the genus Pseudomonas (Wayne et al., 1987). Strain M6 showed 99\% DNA similarity to $\mathrm{M}^{\mathrm{T}}$ and it can be concluded that they belong to the same genospecies. The DNA G $+\mathrm{C}$ contents of $\mathrm{M}^{\mathrm{T}}$ 


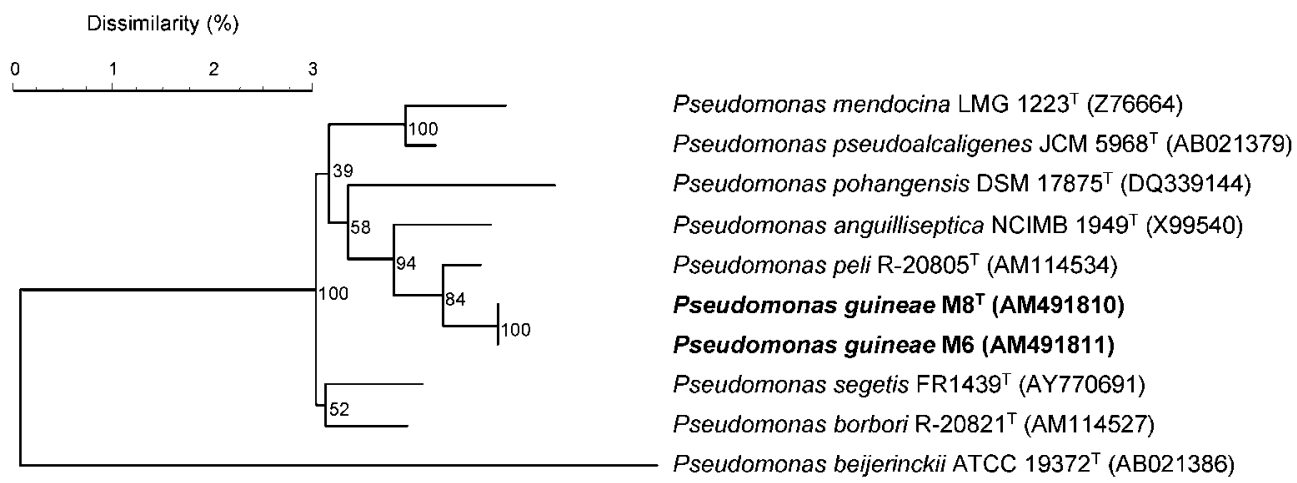

Fig. 1. Phylogenetic tree obtained by neighbour-joining analysis of $16 \mathrm{~S}$ rRNA gene sequences, showing the position of the Antarctic isolates $\mathrm{M}^{\top}$ and $\mathrm{M} 6$ among neighbouring species of the genus Pseudomonas. Bootstrap values $>70 \%$ (based on 1000 replications) are shown at branch points.

and M6 (58.5 and $58.4 \mathrm{~mol} \%$, respectively) lie within the range described for members of the genus Pseudomonas.

The morphological, physiological, chemotaxonomic and phylogenetic data showed that strains $\mathrm{M} 8^{\mathrm{T}}$ and $\mathrm{M} 6$ belong to the genus Pseudomonas. The DNA-DNA hybridization analyses clearly distinguished strain $\mathrm{M}^{\mathrm{T}}$ from $P$. peli (Vanparys et al., 2006) and P. anguilliseptica (Wakabayashi \& Egusa, 1972). On the basis of the data from this polyphasic study, therefore, it is proposed that strains $\mathrm{M} 8^{\mathrm{T}}$ and M6 represent a novel species of the genus Pseudomonas, for which the name Pseudomonas guineae sp. nov. is proposed.

\section{Description of Pseudomonas guineae sp. nov.}

Pseudomonas guineae (gui.ne' ae. N.L. gen. masc. n. guineae of Guinea, in honour of the late Professor Jesús Guinea, a prominent Spanish microbiologist, who isolated this strain).

Cells are rod-shaped $(0.4-0.5 \mu \mathrm{m}$ wide and $1.5-2.0 \mu \mathrm{m}$ long), Gram-negative, non-spore-forming and do not produce fluorescent pigment on King's B medium. Cells are motile by means of polar flagella. After $72 \mathrm{~h}$ incubation at $15{ }^{\circ} \mathrm{C}$ on TSA, colonies are $1.5-2.0 \mathrm{~mm}$ in diameter, smooth and round with irregular edges. Growth occurs at temperatures between -4 and $30{ }^{\circ} \mathrm{C}$, but not at $37^{\circ} \mathrm{C}$. $\mathrm{NaCl}$ is tolerated at concentrations up to $4 \%(\mathrm{w} / \mathrm{v})$. Growth is very poor under anaerobic conditions. Enzyme activities and details of the carbon sources utilized are given in Table 1. The DNA G $+\mathrm{C}$ content is $58.5 \mathrm{~mol} \%$.

The type strain, $\mathrm{M} 8^{\mathrm{T}}\left(=\mathrm{LMG} 24016^{\mathrm{T}}=\mathrm{CECT} 7231^{\mathrm{T}}\right)$, was isolated from a soil sample collected from Deception Island (South Shetland Islands, Antarctica).

\section{Acknowledgements}

This paper is dedicated, with sorrow, respect and gratitude, to the memory of Jesús Guinea Sánchez, who died on 29 September 2006. We would like to thank Josefina Castellví for providing Antarctic samples. We gratefully acknowledge the assistance of F. Garcia (Departament d'Agricultura, Ramaderia i Pesca, Generalitat de Catalunya, Spain) with the fatty acid analysis. We thank the BCCM/LMG Identification Service (BCCM/LMG Bacteria Collection, Laboratorium voor Microbiologie, University of Ghent, Ghent, Belgium) for performing hybridization analyses and 16S rRNA gene sequence analysis. We would also like to thank Dr H. G. Trüper for advice on Latin nomenclature. This research was supported by the Autonomous Government of Catalonia, Spain (grant 2005SGR00066).

\section{References}

Antranikian, G., Vorgias, C. E. \& Bertoldo, C. (2005). Extreme environments as a source for microorganisms and novel biocatalysts. Adv Biochem Eng Biotechnol 96, 219-262.

Anzai, Y., Kim, H., Park, J. Y., Wakabayashi, H. \& Oyaizu, H. (2000). Phylogenetic affiliation of the pseudomonads based on 16S rRNA sequence. Int J Syst Evol Microbiol 50, 1563-1589.

Bozal, N., Montes, M. J., Tudela, E., Jiménez, F. \& Guinea, J. (2002). Shewanella frigidimarina and Shewanella livingstonensis sp. nov. isolated from Antarctic coastal areas. Int J Syst Evol Microbiol 52, 195-205.

Bruni, V., Gugliandolo, C., Maugeri, T. \& Allegra, A. (1999). Psychrotrophic bacteria from a coastal station in the Ross Sea (Terra Nova Bay, Antarctica). New Microbiol 22, 357-363.

Cleenwerck, I., Vandemeulebroecke, K., Janssens, D. \& Swings, J. (2002). Re-examination of the genus Acetobacter, with descriptions of Acetobacter cerevisiae sp. nov. and Acetobacter malorum sp. nov. Int $J$ Syst Evol Microbiol 52, 1551-1588.

Cowan, S. T. \& Steel, K. J. (1993). Manual for the Identification of Medical Bacteria, 3rd edn. Edited by G. I. Barrow \& R. K. A. Feltham. Cambridge: Cambridge University Press.

Ezaki, T., Hashimoto, Y. \& Yabuuchi, E. (1989). Fluorometric deoxyribonucleic acid-deoxyribonucleic acid hybridization in microdilution wells as an alternative to membrane filter hybridization in which radioisotopes are used to determine genetic relatedness among bacterial strains. Int J Syst Bacteriol 39, 224-229.

Goris, J., Suzuki, K., De Vos, P., Nakase, T. \& Kersters, K. (1998). Evaluation of a microplate DNA-DNA hybridization method compared with the initial renaturation method. Can J Microbiol 44, $1148-1153$ 
Kersters, K., Ludwig, W., Vancanneyt, M., De Vos, P., Gillis, M. \& Schleifer, K. H. (1996). Recent changes in the classification of the pseudomonads: an overview. Syst Appl Microbiol 19, 465-477.

King, E. O., Ward, M. K. \& Rainey, D. E. (1954). Two simple media for the demonstration of pyocyanin and fluorescein. J Lab Clin Med 44, 301-307.

Kriss, A. E., Mitskevich, I. N., Rozanova, E. P. \& Osnitskaia, L. K. (1976). Microbiological studies of the Wanda Lake (Antarctica). Microbiology (English translation of Mikrobiologiya) 45, 1075-1081 (in Russian).

Ma, Y., Wang, L. \& Shao, Z. (2006). Pseudomonas, the dominant polycyclic aromatic hydrocarbon-degrading bacteria isolated from Antarctic soils and the role of large plasmids in horizontal gene transfer. Environ Microbiol 8, 455-465.

Maugeri, T. L., Gugliandolo, C. \& Bruni, V. (1996). Heterotrophic bacteria in the Ross Sea (Terra Nova Bay, Antarctica). New Microbiol 19, 67-76.

Mesbah, M., Premachandran, U. \& Whitman, W. B. (1989). Precise measurement of the $\mathrm{G}+\mathrm{C}$ content of deoxyribonucleic acid by highperformance liquid chromatography. Int J Syst Bacteriol 39, 159-167.

Niemann, S., Puehler, A., Tichi, H. V., Simon, R. \& Selbitschka, W. (1997). Evaluation of the resolving power of the three different fingerprinting methods to discriminate among isolates of a natural Rhizobium meliloti population. J Appl Microbiol 82, 477-484.
Reddy, G. S. N., Matsumoto, G. I., Schumann, P., Stackebrandt, E. \& Shivaji, S. (2004). Psychrophilic pseudomonads from Antarctica: Pseudomonas antarctica sp. nov. and Pseudomonas proteolytica sp. nov. Int J Syst Evol Microbiol 54, 713-719.

Shivaji, S., Rao, N. S., Saisree, L., Sheth, V., Reddy, G. S. N. \& Bhargava, P. M. (1989). Isolation and identification of Pseudomonas spp. from Schirmacher Oasis, Antarctica. Appl Environ Microbiol 55, 767-770.

Vanparys, B., Heylen, K., Lebbe, L. \& De Vos, P. (2006). Pseudomonas peli sp. nov. and Pseudomonas borbori sp.nov., isolated from a nitrifying inoculum. Int J Syst Evol Microbiol 56, 1875-1881.

Wakabayashi, H. \& Egusa, S. (1972). Characteristics of a Pseudomonas sp. from an epizootic of pound-cultured eels (Anguilla japonica). Bull Jpn Soc Sci Fish 38, 577-587.

Wayne, L. G., Brenner, D. J., Colwell, R. R., Grimont, P. A. D., Kandler, O., Krichevsky, M. I., Moore, L. H., Moore, W. E. C., Murray, R. G. E. \& other authors (1987). International Committee on Systematic Bacteriology. Report of the ad hoc committee on reconciliation of approaches to bacterial systematics. Int J Syst Bacteriol 37, 463-464.

Wilson, K. (1987). Preparation of genomic DNA from bacteria. In Current Protocols in Molecular Biology, pp. 2.4.1-2.4.5. Edited by F. M. Ausubel, R. Brent, R. E. Kingston, D. D. Moore, J. G. Seidman, J. A. Smith \& K. Struhl. New York: Green Publishing \& Wiley-Interscience. 